\title{
1. Introduction: the collaborative analysis of intelligence
}

\section{Thierry Delpeuch and Jacqueline E. Ross}

\section{LOCAL SECURITY PARTNERSHIPS AND THE COLLABORATIVE STYLE OF INTELLIGENCE ANALYSIS}

Gathering and analyzing information is something that police intelligence units are thought to do in relative isolation. The collection and analysis of intelligence has traditionally been the purview of well-insulated investigators and analysts who belong to specialized police divisions focusing on organized crime, drug trafficking, and terrorism. But intelligence work in the United States and many other democracies has been significantly transformed in recent years. It has become more collaborative, melding the police with an array of other actors. The confluence of three separate developments has driven this process. First, the rise of evidence-based approaches to law enforcement and crime prevention has placed a premium on creating dialogue among a heterogeneous mix of experts. Second, the police have increasingly come to value cooperation and intelligence inputs from a wider range of local and international sources, prompting efforts by intelligence analysts to make greater use of security partnerships. And third, law enforcement increasingly understands the need to build trust and enhance legitimacy in local communities. Trust and legitimacy encourage local leaders to report suspicious behavior, identify crime patterns, and predict riots and other threats to public order.

Over the past several decades, accordingly, police have changed the ways they make sense of the world by including a mix of outsiders in their process of acquiring and assessing information. Successive waves of reforms have introduced community policing, problem-oriented policing, and intelligence-led policing into the day-to-day practices of law enforcement agencies in the English-speaking world and, increasingly, elsewhere. Many of these initiatives embrace what we call the 'partnership paradigm', in which law enforcement works with outsiders to analyze intelligence 
and develop solutions collaboratively. Police, outside experts and local residents address concerns ranging from petty nuisances and local offenses through transnational organized crime and terrorism. These deliberative partnerships have allowed participants to work out coordinated solutions that call on the skills of urban design specialists, social workers, school officials, transportation companies, public housing officers, and administrative officers who enforce municipal housing codes. Tenants' associations and local residents are often included in these ventures. At the national level, law enforcement agencies have attempted to integrate local intelligence analysis with national initiatives to track the movements of criminal organizations and the recruitment tactics of terrorist networks. Liaison officers and diplomats concerned with promoting European integration and improving police cooperation work together to facilitate access to international databases and to coordinate interventions and strategy at the international level.

This volume examines the ways in which the partnership paradigm transforms how the police make sense of their environment, and, specifically, the ways in which participants gather, analyze, and use intelligence about security problems ranging from petty nuisances and violent crime to urban riots, organized crime, and terrorism. How have these emerging collaborative ventures reshaped the way police and other security professionals define and prioritize these concerns? How have the expanding range of stakeholders and the growing repertoire of solutions transformed both the expertise and the deliberative processes involved in addressing such concerns?

The partnership paradigm has increased the range of problems and the types of explanations that the police must consider. Security partnerships have also fostered new forms of expertise and have expanded the list of people and the repertoire of resources on which the police can draw in developing joint analyses of security problems. The contributors examine how experts in urban design, situational crime prevention, crime mapping, and social work analyze local crime problems and develop preventive approaches. The chapters suggest that police participants in such partnerships function both as intermediaries with the local population and as informational relays to intelligence analysts. At the same time, the volume juxtaposes open, heterogeneous partnerships with closed law enforcement networks and examines the ways in which police tactics influence the willingness of the public to share intelligence and to cooperate with the police in partnership deliberations. 


\section{POLICE RECEPTIVITY AND RESISTANCE TO THE PARTNERSHIP PARADIGM}

This volume contributes to - and challenges - a growing literature that tracks the development of a partnership paradigm and of knowledgebased policing in democratic societies, as well as police resistance to such reforms.

Many of the contributors to this volume take entrenched forms of resistance to change as a starting point but map the power dynamics that make some segments of the police receptive to the partnership paradigm and to knowledge-based policing while others remain resistant. The collection explores the power struggles, career incentives, and interpretive approaches that give gang units, for example, a different outlook on crime problems from those prevalent among community policing specialists, patrol officers, or members of vice squads. Contributors highlight the influence of particular types of performance measures, available investigative tools, and resource constraints on the ways in which the partnership model and knowledge-based approaches are absorbed by different units of the police, and how such models or approaches, once absorbed, are transformed and adapted to system- and unit-specific constraints.

The authors also identify factors that give the police incentives to collaborate with outside partners. For example, working relationships with municipal agencies, social workers, housing officials and transport companies allow the police to redefine certain security problems in ways that bring them into the professional purview of these non-police actors. Allowing their partners to handle certain problems through treatment plans, recreational programs, or nuisance abatement permits the police to reduce demands on their own time and resources. Even when the police retain primary responsibility for handling certain types of problems, collaborative analysis and input from outsiders help the police to experiment with a greater variety of preventive approaches.

Non-police actors also have increased technological sophistication and improved tools for tracking crime trends and identifying offenders, making these partners more useful to the police as sources of information. And reforms inside the police have created new career paths and advancement opportunities for officers skilled in making themselves a resource for their community partners as well as their commanders. In cities in which communications between police and the local population had broken down, institutional partners outside of the police became particularly important to the police as intermediaries and informational relays. The contributing scholars suggest that the partnership paradigm sometimes makes police more receptive to innovation and outside forms of expertise, 
which police often resist when imposed from above through the command hierarchy. Accordingly, contributions highlight the extent to which police adoption of situational crime prevention and new techniques for crime trend analysis help the police to promote their preferred solutions to problems that are discussed collectively. At the same time, the authors explore the career incentives and institutional arrangements that explain why grassroots experimentation has proven more influential on police practices in some legal systems than in others, and, indeed, why there is considerable variation in partnership arrangements at the local level, even when security governance is relatively centralized.

To illuminate the impact of the partnership model on intelligence collection and analysis, the collection also juxtaposes those forms of intelligence analysis that are conducted by units that work closely with outside partners and rely primarily on open-source intelligence with intelligence analysis conducted by more specialized units that are relatively insulated from outside influence and work primarily in a closed-source environment. In more isolated units, relationships with sources remain bilateral and secret rather than multilateral, open, and deliberative. More traditional intelligence units rarely coordinate their interventions with outsiders, and, when they do, they network primarily with other law enforcement agencies. This contrast between insular intelligence communities and those committed to partnerships with outsiders suggests ways in which outsiders influence the police assessment of crime data and security concerns.

Apart from a contrast between partnership deliberations and more insular forms of intelligence analysis within the police, contributors also explore differences between types of partnerships. Thus, while many works on partnership models of policing focus only on local law enforcement, this collection juxtaposes the deliberative and analytical practices of local security partnerships, which incorporate local stakeholders and a heterogeneous mix of institutional actors, with modes of deliberation and analysis favored by more homogeneous transnational networks of law enforcement professionals. Our volume thus explores the ways in which collaborative intelligence analysis differs when police talk about security problems with outsiders from when they discuss such issues with other law enforcement professionals, either within specialized units within their own agencies or in transnational security networks with police from other countries.

Of course, the purpose for which partnerships are convened varies with the mix of participants. By considering local as well as transnational partnerships, the authors expand the focus of the literature on knowledge-based policing beyond crime-fighting to the broader range of security issues that preoccupy local security partnerships. Matters of shared concern include vandalism, neighborhood conflict, and riots, as 
well as traffic safety, gangs, drug-dealing, petty crime, and homelessness. Because the literature on intelligence-led policing focuses primarily on crime-fighting, and on technical solutions to improving police efficiency, it tends to overlook the ways in which police and their partners debate whether to define a wider array of problems as crime problems at all. This collection focuses on the ways in which police and non-police actors analyze urban unrest, neighborhood conflicts, and quality-of-life issues, and how they decide which problems require a crime-fighting response and which concerns are best addressed through alternative approaches, such as mediation, psychiatric intervention, or improved recreational offerings. The authors thus examine the ways in which agreements and disagreements over these phenomena affect the legitimacy of the police response, influence what the police treat as enforcement priorities, expand the repertoire of solutions, and bring new actors to the fore in analyzing problems and developing pilot projects.

Addressing a broader array of concerns requires diverse forms of expertise contributed by partners outside of the police, such as social workers, public housing authorities, and urban planning specialists. A number of contributors examine the mix of expertise, both internal and external to the police, that partnerships mobilize to interpret security data, and the ways in which reliance on partnerships has transformed police thinking about crime, risk, and security. Collaborative analysis, the contributors suggest, has changed how problems are defined and priorities are set. Contributors suggest that the partnership paradigm can promote new ways of combining reactive with preventive approaches to problems of crime and security. Drawing on national examples outside the Englishspeaking world, such as Germany and France, the authors compare analytical practices developed by ground-level actors - i.e. a range of bottom-up approaches to intelligence gathering and analysis - with the very different approaches that develop in response to top-down efforts to impose such practices at the national level (as the British have tried to do through their National Intelligence Model).

By considering examples outside the English-speaking world, our contributors are able to examine the unique dynamics of partnership deliberations in a country, such as France, in which the partnership paradigm does not complement community policing but was first introduced in the 1980s and later revitalized to compensate for the weakness of community policing. France abolished community policing in 2003 (and has only recently reintroduced it in a very limited fashion). French experimentation with knowledge-based policing and local security partnerships developed as a way of dealing with the corrosive effects of abolishing community policing, and as a way of building relationships with institutional intermediaries in 
neighborhoods where relations between police and local communities had broken down.

The inclusion of Germany and France alongside the United States and the United Kingdom has also made it possible to consider a greater variety of factors that influence the ways in which knowledge-based policing and partnership paradigms are implemented. Much of the literature on knowledge-based policing and partnerships contrasts Britain, which implemented the partnership paradigm at the national level, through top-down reforms, with the United States, where partnerships arise from grassroots initiatives at the local level. France and Germany are intermediate cases. On the one hand, France is heavily centralized and has enacted enabling legislation nationally to facilitate local security partnerships. Likewise, both France and Germany have national and therefore uniform codes of criminal law and criminal procedure (though Germany has a federal system of governance and police laws that differ across its member states). In both countries, however, the partnership paradigm is implemented differently in each city and receives its impetus, in large part, from grassroots efforts to improve intelligence analysis by experimenting with new forms of expertise and partnership locally. Consideration of these examples reveals differential effects on intelligence analysis of top-down reforms at the national level and local grassroots initiatives.

\section{PARTNERSHIPS: OUTSOURCING OR COLLABORATIVE PROBLEM-SOLVING?}

Peter Manning (2008) insists that collaboration between police and outsiders is of interest to the police primarily because it allows the police to assign surveillance as well as prevention to other private and public institutions and to divest themselves of low-grade crime problems that outsiders can handle through crime-prevention initiatives. Richard Ericson and Kevin Haggerty (1997), too, see the knowledge work of the police as a way for the police to divest themselves of responsibilities while obtaining information that they can pass along to others. Haggerty and Ericson argue that police in the English-speaking world assist other regulatory actors in managing risks by conducting background checks of public sector employees; verifying applicants' eligibility for business and arms licenses; attesting to property being stolen or not stolen; and helping businesses to institute situational crime prevention in order to protect themselves from hacking, break-ins, and industrial espionage. Haggerty and Ericson's work suggests that much police work has been reduced to filling out preformatted forms for private sector partners, leaving the police with little 
maneuver room for proactive initiatives and little discretion in how to classify and characterize risks.

Although this collection also treats police as knowledge workers, the contributors identify a greater diversity of aims than those identified by Haggerty and Ericson. Contributors track a greater diversity of interactions between police and outside partners, finding that informational exchanges are often reciprocal and serve the institutional interests of police and nonpolice actors alike. The extent to which police process and analyze intelligence proactively for crime-fighting purposes varies with the institutional purposes of the relevant unit. The ways in which police process and use intelligence depends on whether they are working in an open- or closedsource environment; whether they are working primarily with other law enforcement agencies in cross-jurisdictional networks or with community stakeholders and other non-police actors; and whether partnerships with outside actors help the police improve their legitimacy in local communities.

Our collection also suggests that the partnership paradigm sometimes allows police - in insular intelligence units and in collaborative networks alike - to take account of what can be done to de-escalate conflict and to incorporate new educational and preventive dimensions into police work that is more traditionally focused on enforcement. At the same time, partnerships lead non-police actors to incorporate more punitive dimensions (such as expulsions from housing, stricter housing code enforcement, and surveillance) into their own repertoire of interventions.

This suggests that collaborative intelligence analysis encourages both police and non-police actors to develop new ways of combining crime prevention with crime detection, and that the distribution of these tasks among partners is not only an effort to outsource police work to others (or for the private sector to outsource its investigative work to the police). While the police experiment with new forms of prevention, their partners assume new responsibilities for assisting the police in detecting and punishing crime, for example through expulsions from public housing, stricter housing code enforcement against suspected gang-members, and increased willingness to share information about perceived troublemakers and low-grade but repetitive offending in problem locations. These hybrid approaches to crime-fighting require greater diagnostic convergence among partners about the causes and triggers of particular problems.

However, the effectiveness with which the police engage with outside experts and partners hinges, to some extent, on the acceptance and legitimacy of the police in the communities they serve. This, in turn, depends not only on the community outreach efforts of the police but also on the ways in which the public perceives police tactics such as heavy reliance on investigative stops and frisking (in the United States), identity checks 
(in France), or counter-terrorism surveillance (everywhere), which have a disproportionate impact on minority communities. The legitimacy of police interactions with local communities, and with minorities in particular, in turn affects the willingness of the public to cooperate with the police, to share information, and to participate in local security partnerships. Ironically, some of the same tactics on which the police rely to generate local intelligence may reduce the influx of intelligence from those who regard police tactics as heavy-handed.

A recurring question, in this regard, is the extent to which partnerships can be used to legitimize a punitive response or to develop alternatives. The extent to which partnerships favor punitive responses or other alternatives may depend on whether local participants in community councils and beat meetings incorporate a representative range of community voices, or whether a more limited range of participants prefers a more divisive approach. Local security partnerships sometimes allow one segment of a community - including some who benefit from urban gentrification or renewal - to mobilize efforts to exclude others who may not be present to protest. Contributions that address the effects of police tactics on the perceived legitimacy of the police note the extent to which enforcement tactics influence the willingness of community members to cooperate with the police and to participate in local security partnerships. Police tactics that alienate a portion of the community can affect the nature of the deliberations that take place in these partnerships and the interests that partnerships are used to advance.

The collection thus challenges two underlying assumptions of many policing studies. The first of these assumptions is that effective tools for improving security and fighting crime must originate externally, outside of the police. The second is that one can generalize about police attitudes and resistance to external forms of expertise without differentiating among the diverse professional cultures, intelligence regimes, and métiers within the police. The conclusion develops a typology of five intelligence regimes within the police to help explain how affinities for certain types of expertise - both external or internal to the police - vary with the problems different units are assigned to resolve, and with the available tools and repertoire of interventions.

\section{INTELLIGENCE-LED POLICING, COMMUNITY POLICING, AND PARTNERSHIPS}

In many ways, this volume builds on the important work of Jerry Ratcliffe, a leading contributor to the literature on intelligence-led policing. In his 
edited volume Strategic Thinking in Criminal Intelligence, Jerry Ratcliffe (2009) defines intelligence-based policing as an 'analysis driven approach to decision-making'. This approach to police work de-emphasizes the reactive management of incoming case flows in favor of a proactive approach to seeking out emerging crime trends, identifying prolific offenders, and disrupting criminal networks. Ratcliffe's work highlights many of the analytical tools that law enforcement agencies use as an aid to decision-making. Ratcliffe (2008), however, views the process of analysis and deliberation as a task that is primarily internal to the police, with outside partners serving mostly as relays and sources of information who do not themselves influence the ways in which the police make sense of intelligence or how the police use such intelligence to formulate crime control policies. This collection contrasts the relatively hermetic intelligence communities that address specialized problem areas inside the police with the heterogeneous and relatively open processes of collective analysis that characterize the joint analysis of a wide range of security problems in the context of local security partnerships.

Part II of this collection thus explores networks of stakeholders and experts both inside and outside the police who develop new crime prevention and risk reduction strategies to supplement and sometimes transform more traditional law enforcement approaches. Wesley Skogan's chapter on community policing in Chicago examines the variety of partnership settings, with a focus on how beat meetings work in a system that values direct contact between police and community residents and allows partnerships to mobilize municipal resources to address an expanding array of public safety concerns. Skogan shows how networks of neighborhood residents worked with the police to identify enforcement priorities, in the process developing new ways of sharing intelligence about crime. Skogan asks how these joint ventures have changed the ways in which law enforcement targets crime and identifies its causes. Police openness to community input recast many quality-of-life concerns as criminal violations. Skogan asks to what extent the groups of neighbors who met with the police mirrored the concerns of the larger communities. The chapter also identifies tensions between quantitative measures of police effectiveness and efforts to involve community residents in crime control policy. Skogan questions the extent to which performance measures reward police responsiveness to community concerns. Do criteria for evaluating the usefulness of intelligence analyses take account of the diverse purposes for which these analyses are negotiated between police, residents, and other institutional stakeholders?

A chapter on France (Delpeuch, Epstein, Ross) in turn compares local security partnerships in three French cities that experimented with 
a variety of new institutional arrangements after France abandoned its experiment with community policing in 2003. This chapter juxtaposes partnerships between police and other institutional actors with security networks composed entirely of law enforcement professionals, who collaborate across national and institutional boundaries.

This empirical study examines the ways in which police in three French cities use local security partnerships to build their ground-level knowledge of local crime problems and how these modes of acquiring intelligence shape security policy and crime control practices. This chapter uncovers the perhaps surprising persistence of local security partnerships after France's abolition of community policing in 2002. It argues that the reduction of direct and informal contacts between police and local residents made security partnerships even more important as sites for the collection and joint analysis of intelligence. The study also shows how institutional partners assumed greater responsibility for addressing the security needs of their communities and found themselves more in need of protection, information, and assistance from the police. The chapter highlights the value of information as a currency of exchange for cooperating partners.

Other chapters in this section address reforms that seek to increase public participation in crime control policy while bypassing and perhaps even weakening collective deliberation in partnership settings. Such reforms, include the decision by police in the United Kingdom to make online crime maps available to the public (discussed by Anna Barker) and the election of local Police and Crime Commissioners in the United Kingdom (discussed by Adam Crawford). These chapters query the effectiveness of such initiatives in encouraging public participation in security governance. The authors explore the ways in which these initiatives intersect with local security partnerships, and they compare the public engagement which these reforms invite with the model of public participation implicit in local security partnerships.

Thus Adam Crawford analyzes British efforts to decentralize security governance through a radical experiment - the creation of Police and Crime Commissioners who are directly elected to set crime control policy at the local level in England and Wales. The commissioners are meant to undo decades of nationalization of crime control policy. Their election increases local accountability by giving the public a direct say in how their streets are policed.

Crawford points out that the new governance structure has been inaugurated at a time of unprecedented decline in police funding. Security functions continue to be outsourced to private security providers. Longterm contracts with private security firms are likely to tie the hands of incoming commissioners. Private security providers may not be subject 
to the same regulations that exist for public police employees. Increased involvement of the private sector may result in segmented regulation but may also foster new working relationships between private sector providers in different domains of crime control. The legislation creating Police and Crime Commissioners does not, however, address whether and how these Commissioners are to work together with local security partnerships. Are the Commissioners meant to contribute to partnership deliberations? Must they take account of the ways in which partnerships diagnose problems and set enforcement priorities? Crawford contends that the reform creates the illusion that voters will be able to choose priorities and set agendas, while the record low turnout suggests that the public was uninformed about the policy questions at issue in the election.

Anna Barker's chapter examines a technological effort to increase democratic participation in crime control policy. Her chapter examines British efforts to provide the public with online access to local crime maps. Like Crawford, Barker questions the effectiveness of British reforms that purport to give the public a voice in setting enforcement priorities and a chance to partner with the police in shaping security policy. Her chapter analyzes the UK's initiative to make local crime maps available online to members of the public. In particular, she explores the extent to which online crime maps strengthen the democratic accountability of the police and contrasts the modes of public engagement such maps invite with the nature of public deliberation about crime data in local security partnerships. Perhaps online crime maps shift some responsibility for security from the state to private citizens. The chapter places crime along a continuum of participatory models of policing, ranging from those that position the user primarily as a passive consumer of crime statistics to others that engage the public in joint deliberation with the police about enforcement tactics and priorities. Online publication also brings unanticipated effects, such as decreased reporting of crime by residents who fear that online access to crime data may diminish the resale value of their homes.

Barker contends that access to online crime data erodes existing hierarchies of knowledge and gives the public a greater role in defining enforcement priorities. But she also addresses concerns that 'crime maps focus on a narrow concept of crime and a restricted conception of policing as crime control'. Barker examines the interpretive challenges such crime maps may pose to their users and suggests that crime maps are useful primarily to specialist or elite audiences, who make use of the information to claim a disproportionate share of policing services.

Contributors also compare how investigators use partnerships to develop new crime-fighting strategies, in spite of the fact that it is difficult to coordinate forms of analysis that rely on open-source information with 
those that rely primarily on confidential sources. Nick Tilley, for example, studies a variety of efforts by British investigators of organized crime to use the partnership model in order to disrupt criminal networks, thus extending the insights of the partnership model beyond local crime-fighting and quality of life issues. Tilley explores the ways in which expanded access to intelligence from local community partnerships helped the British police to develop such strategies.

He focuses, in particular, on the ways in which the police pull together information from a variety of sources - including community contacts, partner agencies, covert operations, police records, and suspicious activity reports - in order to develop strategies aimed at disrupting organized crime. The chapter identifies ways in which intelligence developed in local security partnerships filters through to relatively insular units, like those that combat organized crime. Tilley considers the differences between disruption and other proactive strategies like situational crime prevention and case-building for criminal prosecution. Disruption of organized crime borrows from techniques used to disrupt international terrorism. These include the use of crime-specific databases: (a) to detect links between offender groups involved in seemingly unrelated types of criminal activities; (b) to generate threat assessments; and (c) to identify an organization's points of vulnerability so that these that can be targeted for disruption. Intelligence from local security partnerships plays an increasingly important role in feeding these databases. Unlike traditional law enforcement methods, disruption aims at harm reduction rather than conviction of individual offenders. Though disruption, detection, and prevention overlap, Tilley argues that they have very different aims and methods.

Tilley highlights the extent to which disruption depends on cooperation by non-police actors, including communities in which organized crime seeks to secure a legitimate cover. He emphasizes the importance of strategies aimed at increasing residents' trust in the police and reducing community tolerance of organized crime. Tilley's chapter includes brief case studies of four very different British efforts to disrupt organized crime, by improving police relationships with local businesses, and attending to the concerns of local security partnerships. The case studies allow Tilley to chronicle the failures, successes, and ethical challenges of British efforts to use community outreach to disrupt a variety of criminal organizations.

Like Nick Tilley, Peter Manning highlights differences between the various ways in which different paradigms of police work value and use information. For Tilley, the new paradigm is disruption; for Manning it is intelligence work, and he highlights its differences from traditional, caseoriented modes of policing. In particular, Manning explores the important 
differences between running an intelligence operation and working a criminal case. Case working itself can vary significantly, and Manning distinguishes between reactive case investigations of past offenses, proactive investigations of ongoing crimes, covert surveillance, and informant-based betrayal. He contrasts all four of these, however, with the irrelevance of the individual case for intelligence operations, including computergenerated analyses of crime data from the aggregation of multiple cases, the compilation of bulk data for anti-terrorism investigations, and the intelligence-based mode, which he describes as an effort to manage problems rather than 'crimes', while aggregating information from many sources and many databases, in order to discern deeper patterns.

If case-working and the analysis of bulk data are often the preserve of intelligence communities that are relatively sealed off from outside input, a variety of reforms have sought to give the public greater influence in the analysis of security problems and in the formulation of crime control policy. But collaborative analysis of intelligence not only enriches the analysis of crime problems while expanding the repertoire of solutions with which partnerships experiment, at all levels of security governance, contributors argue, partnerships enhance the legitimacy of the police in their dealings with foreign counterparts and with members of the public, thereby improving trust and ensuring the flow of critical intelligence. But the police must overcome certain impediments to make partnerships more effective as sources of intelligence and as settings in which participants can analyze problems collectively.

\section{PARTNERSHIPS AND LEGITIMACY}

In Part III, accordingly, a number of authors study the ways in which police work outside the context of local security partnerships affects the willingness of communities and of the police themselves to collaborate and to share information. Chapters by Stephen Schulhofer and by Jeffrey Fagan, Tom Tyler, and Tracey Meares investigate the factors that shape residents' willingness to participate in local security partnerships, focusing on police tactics as obstacles to trust. Gauthier, in turn, analyzes outreach efforts by which the police seek to improve their relationships with local communities. And de Maillard and Mouhanna explore the impact of quantitative measures of police performance on the partnership paradigm, suggesting that a command hierarchy that emphasizes quantifiable investigative results systematically undervalues deliberation about crime prevention efforts that do not promise an increase in arrests. If partnerships increase police legitimacy in the eyes of the communities in which 
they are embedded, quantitative performance measures decrease the legitimacy of partnerships in the eyes of the police, because the achievements of local security partnerships are more easily captured through qualitative than through quantitative performance measures.

Thus a number of studies highlight the negative impact of certain traditional law enforcement tactics on police efforts to secure closer cooperation and to obtain intelligence from local communities. As chapters by Stephen Schulhofer and Jeffrey Fagan, Tom Tyler, and Tracey Meares suggest, this quest for improved access to local intelligence in turn gives law enforcement agencies reasons to rethink policing strategies (such as stop-and-frisk practices) that undermine the effectiveness of the partnership model by reducing the willingness of the public to cooperate with the police. The chapter by Fagan, Tyler and Meares examines the way in which exposure to aggressive stop-and-frisk tactics shapes attitudes towards the police, particularly when residents are stopped and frisked without reasonable suspicion. The authors contend that such tactics delegitimize the police. While stop-and-frisk tactics rarely result in arrests or in seizures of weapons or contraband, the authors argue, such tactics erode public trust and confidence in the police, discouraging citizens from participating in local security partnerships or otherwise assisting police in collecting information useful for solving and preventing crimes.

Stephen Schulhofer's chapter specifically examines the impact of such an erosion of public confidence on counter-terrorism intelligence. Empirical research shows that cooperative behavior - for example, people's willingness to report suspicious behavior or to participate in community crime prevention efforts - is strongly associated with their perception that police exercise their authority fairly. Yet with respect to locally centered counter-terrorism policing, the procedural justice findings derived from studies of ordinary law enforcement conceivably might not apply with equal force.

To fill this gap in assessing the potential benefits of a procedural justice approach for counter-terrorism policing, the author's research team conducted approximately one hundred face-to-face interviews in the Muslim communities of New York City and London, followed by a random telephone survey of 300 households. They tried to determine the extent to which the dependent variables of interest (willingness to participate in law enforcement initiatives and readiness to alert law enforcement to suspicious behavior) were correlated with a wide range of independent variables, including: demographics; socioeconomic indicators; cultural and political attitudes; religiosity; views about terrorism, police effectiveness, and civil liberties; social discrimination; and law enforcement practices that target and harass particular communities. 
On the basis of regression analyses of data sets from both New York and London, the study concludes that the willingness of respondents to cooperate drops substantially, and with very high statistical significance, when they believe that the police use unfair counterterrorism procedures. This holds true regardless of respondents' views about deference to authority, the importance of civil liberties, and the other attitudinal variables.

Gauthier, too, explores the ways in which initiatives that improve the legitimacy and acceptance of the police enhance the collection of intelligence. In his chapter on Berlin, Jérémie Gauthier highlights ways in which community outreach programs can expand participation in security partnerships and secure useful intelligence by improving police relationships with immigrant communities. Gauthier uses interviews and extensive fieldwork to explore how specialized units of the Berlin police make contact with recent immigrants. He contrasts these observations with his fieldwork in the suburbs of Paris, where he was embedded with anticrime units of the French National Police. Both Paris and Berlin police units interact regularly with minority populations, with a view to developing local knowledge. But while the Paris anticrime units rely largely on identity checks akin to stop-and-frisk to develop leads about crimes in progress, the Berlin units are largely preventive in focus. They receive specialized training in outreach to immigrant communities in a form of community policing aimed specifically at the city's minority residents. Gauthier's chapter compares and contrasts the ways in which French and German police construct their relationships with immigrant communities; the types of knowledge about these communities that the police develop; and the ways in which these units analyze the information they collect. He suggests that improved understanding of immigrant communities depends on the skill with which outreach efforts enhance police legitimacy in communities that harbor some distrust of the police.

Other contributors identify the ways in which quantitative performance measures make it difficult for the police to attend to the concerns of their partners and for police managers to assess the value of local security partnerships for the police. Christian Mouhanna and Jacques de Maillard study the performance indicators and criteria by which the French police are evaluated, highlighting the ways in which these performance measures shape the law enforcement role in local security partnerships. The authors contend that the command hierarchy has imposed quantitative measures that discourage the police from attending to quality of life concerns raised in local security partnerships. The chapter also argues that pressure to demonstrate a rise in arrest figures leads the French police to overvalue intelligence that helps them build criminal cases and to undervalue partnership deliberations about how to prevent crime. They worry 
that quantitative performance measures fail to reward outreach efforts designed to improve police relationships with local communities, while leading the police to over-rely on identity checks and security sweeps that generate resentment in the communities whose support the police need to improve their access to intelligence.

At the international level, Part IV of this volume includes a number of contributions examining transnational networks of liaison officers who use their access to specialized databases as leverage to facilitate the transnational exchange of intelligence. These chapters also examine the role of trust in facilitating the exchange of personal data across national borders. In particular, they study how law enforcement officers who participate in international crime-fighting networks decide when to rely on informal bilateral arrangements and when to resort to formal international agreements. These contributions juxtapose various types of networks and partnerships with each other, examining the differences between the modes of intelligence analysis conducted by relatively closed networks of experts at the international level, on the one hand, and the types of negotiated, collective analysis, on the other, that grow out of more open partnerships between a mix of different institutional actors and community stakeholders.

This Part complements previous discussions of partnership dynamics by contrasting transnational collaboration among law enforcement professionals with highly local cooperation between police, residents, and institutional partners outside of the police. The chapters in this section explore the dynamics of intelligence sharing and cooperation among transnational liaison officers for law enforcement agencies and among law enforcement networks of the European Union. These contributions contrast the forms of trust and the norms of reciprocity that facilitate international cooperation among law enforcement professionals with the preconditions for information exchange, coordination of diverse interventions, and mutual confidence among the more heterogeneous participants in local security partnerships.

Frédéric Lemieux and Chantal Perras, in particular, investigate how liaison officers posted to Washington DC work together with their foreign and American counterparts. Lemieux and Perras examine liaison officers' strategies for responding to their partners' requests for assistance and for establishing norms of reciprocity that allow them to advance their own governments' law enforcement agenda. The chapter delves into the ways in which prior experience in a domestic law enforcement agency shapes these interactions and determines the ways in which liaison officers can make themselves useful to other members of transnational law enforcement networks. The authors highlight the distinct networking skills and 
expertise developed by liaison officers who have prior operational backgrounds in drug interdiction and the investigation of organized crime. Lemieux and Perras contrast the networking styles of seasoned criminal investigators with those of liaison officers who are, primarily, diplomats.

Hartmut Aden's chapter tracks the efforts of the European Union to harmonize the standards for data protection across the Member States in order to improve the exchange of personal data between law enforcement agencies. Aden surveys the role that centralized databases play in facilitating the exchange of law enforcement intelligence and argues that informal police relationships continue to play a vital role in compensating for the inadequacies of existing databases.

The chapter highlights the limitations of the regulatory framework for data protection that was established by the Treaty of Lisbon. Aden distinguishes the types of trust that can best be enhanced through informal, bilateral arrangements from those that presuppose formal international arrangements. Aden also explores the ways in which legal instruments can build trust among cooperating police agencies. He distinguishes among the different types of trust on which cooperation depends, such as trust in what is done with information (how it is used), trust in the other actor's legal system, trust in shared operational objectives, trust in the accuracy of information that is obtained, and trust in the reciprocity of exchanges when a future quid pro quo is expected. In so doing, he juxtaposes the dynamics of law enforcement networks with those of the local security partnerships among police and non-police actors that are explored in Part II of the volume.

\section{HOW PARTNERSHIP AND COLLABORATION CHANGE THE ROLE OF INTELLIGENCE IN CRIME CONTROL STRATEGY}

Pioneering research by Jenny Fleming and Jennifer Wood (2006), Clifford Shearing and Jennifer Wood (2003) and Benoît Dupont (2004) looked closely at the power struggles and exchanges that take place in security partnerships and at how cooperating institutions shape their respective fields of action and distribute roles between themselves. Collecting diverse empirical examples of network structures in the field of security, these authors look at risk and security as constructed categories that have different meanings for different institutional actors. In Imagining Security, for example, Wood and Shearing explore the diversity of ways in which states relate to other institutional players in the field of security, including the range of ways in which state and non-state actors negotiate 
differences between their respective interests, institutional outlooks, and technological resources.

These authors identify a number of challenges that intelligence analysts must overcome in order to better integrate outside perspectives. Political and hierarchical demands on the police are often driven by election cycles. Accordingly, police are often under pressure to produce quick improvement in crime rates, even though partnerships often pursue strategies whose impact will only be felt long-term. Thus, intelligence analysts must take account not only of constraints on police resources but of the political and institutional constraints on police as well as their outside partners. To illuminate the ways in which partners accommodate these outside pressures, the authors call for research into the ways in which intelligence analysis has itself become a collaborative endeavor.

Our collection takes up this challenge to study the ways in which security partnerships have transformed the collection and analysis of intelligence. Our contributors examine the ways in which collaborative analysis has changed the ways in which security problems are defined and has expanded the range of expertise brought to bear on assessing their causes.

At the same time, our volume brings into focus how partnerships that link preventive or anticipatory tasks with a past-oriented 'justice' approach have influenced the way intelligence is analyzed internally. For example, in American cities in which gang violence is a primary concern, analysts who participate in community partnerships are able to track shifting membership patterns and the fragmentation of gangs into competing cells. Working together with housing officials, gang specialists within the police, and intelligence units that can mobilize rapid intervention teams, community liaison officers can help gang investigators build cases against gang leaders, coordinate municipal code enforcement, and mobilize squad cars to saturate neighborhoods where retaliatory gang violence is predicted. This enables analysts to identify and address both immediate concerns about impending outbreaks of gang violence, and to remediate 'hot spots' where gang-members congregate and violence is recurrent. Likewise, we examine emerging alliances between analysts who participate in partnership networks and drug interdiction units whose vision of crime problems often competes with the perspectives of organized crime, vice, and gang units, which view many of the same phenomena through different lenses.

Accordingly, the contributors to this volume track the ways in which the partnership model has opened even relatively insular and specialized units of the police to outside influence. At the same time, our authors argue that important differences remain between the ways in which the police analyze intelligence internally and the ways in which they make sense of 
crime when they deliberate with their partners. Thus, while many authors continue to regard what the police do in monolithic terms, treating 'the police' itself as a relatively integrated unit of analysis, we here distinguish among the types of intelligence practiced by different units within the police, to bring out the ways in which intelligence analysis conducted by those actively engaged in security partnerships differs.

We also take up the suggestion advanced by Wood and Shearing in Imagining Security that more attention be devoted to a comparison of how security networks function at the local and international levels. Imagining Security demonstrates the existence of affinities between highly local networks and the global governance of security through groupings of civic society, partnerships between the military and private contractors in war zones, and global partnerships in the identification and investigation of terrorist threats. Many of our contributors examine such networks as knowledge communities. We contrast the ways in which international networks of security professionals exchange intelligence and make sense of it with the ways in which more heterogeneous networks transmit information and arrive at shared understandings.

Most scholars of policing continue to regard the police as the most powerful player in security partnerships. We argue, however, that local security partnerships have gradually shifted power to a variety of outside participants, who have increasingly influenced how information is analyzed. Outside actors often have privileged access to information, and law enforcement must defer to interpretations offered by partners whom the police increasingly regard as valuable intermediaries with restive populations and uncooperative partners.

We also build on the insight, advanced by Wood, Shearing, Fleming, and Dupont, that security networks have blurred the line between the preventive tasks traditionally associated with non-state actors and the "pastoriented "justice" perspective once associated exclusively with the police. These approaches are increasingly melded together, with both types of tasks undertaken by all types of institutional actors across the publicprivate divide. Contributors to our volume trace the influence of the expanded repertoire of solutions advanced by outside partners on the ways in which the police interpret security problems and understand their options in addressing them.

In this regard, we also test and develop the suggestion of Shearing and Wood $(2000,2003)$ that weak actors in security networks can leverage their local knowledge and resources to draw more advantage from the networks in which they participate, so they can not only be enlisted as resources by others but can in turn enlist other actors to address their own concerns. Shearing and Wood $(2000,2003)$ used the example of South African peace 
committees and Argentinian human rights organizations to identify tactics that improve weak actors' bargaining power in security networks and their value to institutional partners. Several of the contributors discuss ways in which a range of outside experts - including urban development specialists, health workers who specialize in the treatment of addiction, educators, local crime observatories, and social workers who study the effectiveness of different types of mediation - influence the collective analysis of local crime problems as well as deliberations about how best to address them. Contributors reveal the ways in which the police sometimes enlist these forms of expertise to advance their own agenda in local security partnerships, while, at other times, co-opting these specialists or developing their own increasingly sophisticated forms of expertise and hiring or training their own experts to supplement, counter, or compete with the analyses advanced by outside specialists.

Finally, we explore both the cohesion-building and the divisive potential of collaborative intelligence analysis. While community outreach initiatives by police can increase the range of participants in local security partnerships, and give voice to a variety of stakeholders, the partnership model also holds an illiberal potential to pit segments of a community against each other, if police practices sufficiently alienate a portion of the community. Police tactics that reduce the willingness of community members to share intelligence or cooperate with the police in a partnership setting can reduce participation and skew collaboration between police and local communities in favor of stakeholders and community members who demand a more active police presence, at the expense of alienated community members who are themselves most likely to become the objects of increased police surveillance. (For example, Desmond, Matthew and Valdez (2013) suggest that the strategy of expelling gang-members from public housing often ends up hurting the victims of domestic abuse.) Tensions between participants and non-participants in local community partnerships can be exacerbated when gentrification and urban renewal projects create divisions and conflicts of interests among those most likely and those least likely to benefit from economic changes to their neighborhoods.

\section{REFERENCES}

Desmond, Matthew and Valdez, Nicol (2013) 'Unpolicing the Urban Poor: Consequences of Third-Party Policing for Inner-City Women', American Sociological Review, 78: 117-141.

Dupont, Benoît (2004) 'Security in the Age of Networks', Policing and Society, 14(1): 76-91. 
Ericson, Richard and Haggerty, Kevin (1997) Policing the Risk Society, Toronto: University of Toronto Press.

Fleming, Jenny and Wood, Jennifer (2006) Fighting Crime Together: The Challenges of Policing and Security Networks, Sydney: University of New South Wales Press.

Manning, Peter K. (2008) The Technology of Policing: Crime Mapping, Information Technology, and the Rationality of Crime Control, New York: New York University Press.

Ratcliffe, Jerry (2008) Intelligence-Led Policing, Cullompton: Willan Publishing.

Ratcliffe, Jerry H. (ed.) (2009) Strategic Thinking in Criminal Intelligence, 2nd edition, Sydney: The Federation Press.

Shearing, Clifford and Wood, Jennifer (2000) 'Reflections on the Governance of Security: A Normative Inquiry', Police Practice, 1(4): 457-476.

Shearing, Clifford and Wood, Jennifer (2003) 'Nodal Governance, Democracy, and the New "Denizens", Journal of Law and Society, 30(3): 400-419.

Wood, Jennifer and Shearing, Clifford (2013) Imagining Security, Abingdon: Routledge. 
Thierry Delpeuch and Jacqueline E. Ross - 9781785361036

Downloaded from PubFactory at 04/26/2023 01:58:46PM via free access 